\title{
A Review on the Production and Culture Techniques of Monosex Tilapia
}

\author{
Avishek Bardhan ${ }^{1}$, S. K. Sau ${ }^{2 *}$, Sanjib Khatua ${ }^{2}$, Madhabendu Bera ${ }^{2}$ and B. N. Paul ${ }^{3}$ \\ ${ }^{1}$ Department of Aquatic Animal Health, ${ }^{2}$ Department of Aquaculture, Faculty of Fishery \\ Sciences, West Bengal University of Animal and Fishery Sciences, 5, Budherhat Road, \\ Chakgaria, Panchasayar, Kolkata, West Bengal, India \\ ${ }^{3}$ ICAR - Central Institute of Freshwater Aquaculture (CIFA), Regional Research Centre, \\ Rahara, Kolkata, West Bengal, India
}

*Corresponding author

\section{A B S T R A C T}

\section{Keywords}

Tilapia,

Oreochromis

niloticus, Monosex

tilapia, Monosex

culture, Monosex

Article Info

Accepted:

08 December 2020

Available Online:

10 January 2021
Tilapia ranks second among the most cultured fish globally. It is also the most important farmed non-cyprinid fish accounting for over $20 \%$ of the global aquaculture production (6.6 million tonnes). To make up for anticipated deficits or losses in wild harvest, the tilapia industry is retorting, not only in its former strongholds throughout Southeast Asia, but also in the Americas and Africa. The candidate aquacultured species of the tilapiine family is the Nile tilapia (Oreochromis niloticus), which is known for its superior growth rates and attainment of large market sizes over a wide range of environmental parameters. Its disease resistance and ability to efficiently flex its feeding habits also make it an ideal species for culture. The increased production in tilapia has been recognized on extensive research efforts, with the most significant gains achieved by utilizing monosex production techniques. Monosex tilapia is a new technological product in this aquacultural era.

\section{Introduction}

Capture fisheries production has reached a stagnant stage and is no longer considered capable of sustaining the supply of fisheries products for the growing global demand (Subasinghe et al., 2009). Tilapia has the potential to play a crucial role in the fight against food insecurity and malnutrition (FAO, 2012; 2017; El-Kassas et al., 2020) and has been the only cichlid (Order: Perciformes) maintaining stable market prices across the globe (Wang and Lu, 2016).
Tilapia is one of the most consumed farmed fishes in the world and the most important cultured non-cyprinid fish globally, with a total production of 6.6 million tonnes in 2019 , most of which came from countries outside of their natural habitat in Africa and the Levant (Prabu et al., 2019; El-Kassas et al., 2020). It is hardy, environment-friendly and has good resistance to diseases; they are reasonably priced and easy even for small fishers to grow (El-Sayed, 2019). In addition to this, the growing health awareness among people regarding protein-rich diet also enhanced the 
demand for tilapia since it contains essential vitamins and omega-3 fatty acids (Karim et al., 2017; El-Sayed, 2019). Moreover, the developments in genetic technology, selective breeding and increasing government initiatives to support aquaculture business are also stimulating the growth of the tilapia market (Prabu et al., 2019). The bulk (80\%) of the production comes from a single species, the Nile tilapia (Oreochromis niloticus) (Prabu et al., 2019; Mengistu et al., 2020; El-Kassas et al., 2020). There are about 70 species of tilapia amongst which 10 species find its use in aquaculture worldwide (El-Sayed, 2019). Tilapia are primarily herbivorous and detritivorous feeders. However, the presence of flexible and opportunistic feeding behaviour has made them an ideal species for aquaculture (Karim et al., 2017). The development of sex-reversal techniques using hormones in the 1970s led to the production of male monosex populations to be raised to uniform, marketable sizes (Thongprajukaew and Rodjaroen, 2020). In monosex culture, males are preferred because they have a faster growth rate than females (Chávez-García et al., 2020). It serves as an important source of income throughout the world (Sosa et al., 2005). The monosex male population of tilapia are well recognized for increased production potential and low management requirements (El-Sayed, 2019). Over the ages, tilapia has become the shining star of aquaculture and popularly known by different names like 'aquatic chicken', 'fish of the 1990s' and 'food fish of the 21st century' (Costa-Pierce and Riedel, 2000; Ramnarine and Singh, 2005).

\section{History of monosex tilapia and its initial production}

The exhibition of sub-optimal growth and variable sizes were the frequent constraints of mixed-sex populations of tilapia commercial culture before 1970s (Noakes and Balon,
1982; Fuentes-Silva et al., 2012). The initial attempts to produce all-male fry in order to circumvent the foresaid problem began in the 1970s. Although it looked promising, no suitable technology for reliably producing allmale tilapia at a commercially viable scale emerged until the mid-1980s. Development of hapa-based culture allowed for the assortment of tilapia eggs and yolk-sac larvae of a uniform age and proved to be the key in ensuring consistently high ( $99 \%)$ levels of male fish following the application for 21 days of feed augmented with 17- $\alpha$ methyltestosterone (Gale et al., 1996; Popma and Lovshin, 1996). This breakthrough befell as a result of research instigated by the Asian Institute for Technology (AIT) in 1984 as a part of an EU funded project on septage-fed aquaculture systems. After late 1990's, the number of monosex hatcheries flourished as commercial demand for sex-reversed fry increased and knowledge of the necessary hatchery management techniques, once confined mostly to researchers associated with the early development of the technology, became more accessible. The ability to produce monosex tilapia has revolutionised the profile of the species' production and consumption.

\section{Monosex tilapia production techniques}

The major drawback of tilapia pond culture is the high level of unrestrained reproduction that may occur in grow-out ponds (Little and Hulata, 2000; Felix et al., 2019). Monosex culture is one of the methods of restraining uncontrolled tilapia populations (Green et al., 1997; Little and Hulata, 2000; Wang et al., 2019). Monosex production techniques include the labour-intensive hand-to-hand separation of sexes, environmental alterations, hybridization, hormonal augmentation (sex reversal) and laboratory genetic manipulation methods such as androgenesis, gynogenesis, polyploidy and transgenesis (Felix et al., 
2019). None of these methods is consistently $100 \%$ effective, and thus an amalgamation of methods is suggested. Males grow almost twice as fast as females, which may be caused by a sex-specific physiological growth capacity, female mouth-brooding or the more aggressive feeding behaviour of males (Kembenya, 2020). Expected survival rate of monosex culture is proved to be above $90 \%$ (Abo-Al-Ela, 2018). The percentage of females mistakenly included in a population of mostly male tilapia affects the maximum attainable size of the original stock in growout phase. Male tilapia production has an economic importance. The increase in employment in the sector in view of the world population growth is a crucial source of income and livelihood for hundreds of millions of people around the world (SotoZarazúa et al., 2011). It could play a pivotal role in providing food security for the general population as an excellent source of highquality protein (El-Sayed, 2019).

\section{Manual sorting}

Some species of the genus tilapia can be easily sorted into males and females based on their secondary sexual characteristics like colour or the structure of the urogenital papilla (Felix et al., 2019). A second check has to be made when the fish have grown larger and distinctive sex-coloration is more discernible.

The manual sorting of small tilapias based on their sex, although feasible, is tiresome and not entirely trustworthy (Prabu et al., 2019). Additionally, it is stressful for the fish. Human accuracy varies between $80 \%$ and $90 \%$ entailing for errors in the range of $3-10 \%$ (Felix et al., 2019). For this reason, this method is rarely used (Penmann and McAndrew, 2000). This technique may be useful in small populations like backyard aquaculture but unfit for commercial purposes.

\section{Environmental temperature manipulation}

Tilapia is a thermo-sensitive species (Prabu et al., 2019). The male to female proportion changes with temperature and/or ovarian differentiation (Mengistu et al., 2020). Temperature treatments must be made at critical periods of time. Molecular mechanisms of thermo-sensitivity could be addressed in tilapia species ( $O$. niloticus), where aromatase gene expression is downregulated by masculinising temperature treatments (Baroiller et al., 2009). Baroiller et al., (1995) demonstrated that tilapias were sensitive to temperature during the period of sex differentiation and there is a possibility to masculinise XX progenies (100\% females) with elevated temperatures (above $32^{\circ} \mathrm{C}$ ). High temperatures could capably masculinise some offspring if started around 10 days post fertilization (Baroiller et al., 2009). However, if a treatment was made for a 10-day period beginning at 7 days post fertilization, it had no consequences on sex ratios (Baroiller et al., 1995). Unfortunately most of these studies regarding temperature sensitivity are hindered because the sex determination mechanisms of most of these species are less-studied (Baroiller et al., 2009).

\section{Hybridization}

Hybridization aims at the qualitative variances to improve genetics by crossing two closely related but distinct subspecies of fish. Hybrids from various Oreochromis species are listed in the Table 1. A super male Tilapia (YY) can be attained by feminizing genotypic males (XY) with estrogens and then breeding them with normal males (XY), which leads to three different possible progenies: females $(\mathrm{XX})$, males (XY) and super males (YY). This strategy has restrictions, mostly, not being $100 \%$ effective, which implies the possibility of other sex determining factors (Pham and Little, 1998; Francis and Esa, 
2016). The major limitations in producing hybrids are maintenance and purity of brooders, inadequate fecundity and difficulty in producing sufficient hybrid fry due to spawning incompatibilities between the parent species.

\section{Sex reversal or hormonal augmentation by feeding}

This method can be performed by oral administration of feed incorporated with androgen and eggs or fry immersion in different concentrations of the male hormone and probably the most popularly (commercially) used technique (Beardmore et al., 2001; Belton and Little, 2008; Celik et al., 2011; Mehrim et al., 2019; Snake et al., 2020). The principle behind this method lies on the fact that at the stage when the tilapia larvae are said to be sexually undifferentiated (right after hatching up to about 2 weeks or up to the swim-up stage), the extent of the androgen and the estrogen present in a fish is equal (Karim et al., 2017). Thus, augmenting one of the hormones that is originally present in the fish will direct the fish to either male or female depending upon the hormone introduced. Accordingly, if the tilapia larvae are fed with feed incorporated with male hormone viz., 17 $\alpha$-methyltestosterone (MT), the fish will develop into phenotypic male physically and function as male but possess the female genotype (XX) (Beardmore et al., 2001). The list of hormones that have been researched and worked upon on various tilapiine species are mentioned in Table 2. Sex reversed "male" reaches similar average weights as genetically male tilapia (Mair et al., 1995) and it does not require that a portion of the production be discarded (Phelps and Popma, 2000). The presence of hormone residue in adult fish has not yet been studied, thus its effect on consumers is not yet known (Suseno et al., 2020). Hormones may be challenging to obtain in some places and skilled labour with good hatchery facilities are required (Phelps and Popma, 2000). Sex reversal by oral administration of feed (incorporated with $17 \alpha-\mathrm{MT}$ ) is the most effective and practical method for the production of all-male tilapia till date (Celik et al., 2011; Snake et al., 2020). The dose when administered orally differs between 30$60 \mathrm{mg} / \mathrm{kg}$ of feed for total of 25-30 days depending on the intended outcome (Little et al., 2003). It is suggested that the use of 30 $\mathrm{mg} / \mathrm{kg}$ of $17 \alpha$-ET for 18 days will approximately result in production of $98 \%$ of male monosex fish. The use of $60 \mathrm{mg} / \mathrm{kg}$ of feed will produce $100 \%$ male in $O$. mossambicus (Francis and Esa, 2016). The $17 \alpha-\mathrm{MT}$ will give $98 \%$ and $85 \%$ at 30 and 60 $\mathrm{mg} / \mathrm{kg}$ feed. This is an indication that the administration of more than the recommended dose will not add any value to the stock but serve a waste of available resources (Phelps and Popma, 2000; Sayed et al., 2018). However, the technique has minor limitations. Uniform age fish should be used at the first feeding stage to ensure high reversal rate. Moreover, widespread use of vast quantities of androgens in hatcheries may pose a health risk to workers (Mlalila et al., 2015; Francis and Esa, 2016; Sayed et al., 2018; Suseno et al., 2020). This technique has achieved successful results up to $100 \%$ and feed with the male hormone is commercially available or can be prepared (Mlalila et al., 2015).

\section{Hormonal augmentation using immersion methods}

Another alternative of the oral feeding is the use of live bait that has been brought up in a synthetic environment enriched with androgens [17 $\alpha-\mathrm{MT}$ and $17 \alpha$-ET] (Sayed et $a l ., 2018)$. This technique has been used with Nile Tilapia fry and has obtained levels of masculinisation up to 99\% (Phelps and Popma, 2000; Syarifuddin et al., 2019). 
Table.1 A list of different hybrids of Orechromis spp. and their probability of male progeny

\begin{tabular}{|l|l|c|}
\hline Male & Female & Male (\%) \\
\hline O. niloticus & O. aureus & $75-95$ \\
\hline O. aureus & O. niloticus & $50-100$ \\
\hline O. mossambicus & O. aureus & 89 \\
\hline O. hornorum & O. mossambicus & 100 \\
\hline O. macrochir & O. mossambicus & 100 \\
\hline O. macrochir & O. niloticus & 100 \\
\hline
\end{tabular}

(Source: Francis and Esa, 2016)

Table.2 A list of different reported hormones that have been utilized for production of monosex tilapia

\begin{tabular}{|l|l|l|l|}
\hline Species & Hormone & Duration & Male (\%) \\
\hline O. niloticus & Fadrozole & 30 days & $92.5-96$ \\
\hline O. niloticus & $17 \alpha-E T^{*}$ & $25-28$ days & $91-99.4$ \\
\hline O. niloticus & $17 \alpha-\mathrm{MT}^{*}$ & 21 days & 99 \\
\hline O. niloticus & $17 \alpha-$ methyldihydrotestosterone & 4 hours & 100 \\
\hline O. mossambicus & $17 \alpha-$ ET & 18 days & 100 \\
\hline O. mossambicus & $17 \alpha-\mathrm{MT}$ & 18 days & 98 \\
\hline O. aureus & $17 \alpha-\mathrm{MT}$ & 42 days & 100 \\
\hline O. aureus & $17 \alpha-\mathrm{ET}$ & $25-28$ days & $83-97$ \\
\hline
\end{tabular}

(Source: Francis and Esa, 2016; Mukherjee et al., 2018)

* MT: methyltestosterone; ET: ethynyltestosterone

Table.3 Feeding chart of monosex tilapia in respect to their biomass

\begin{tabular}{|c|c|c|}
\hline $\begin{array}{c}\text { Average bodyweight of fish } \\
\text { (grams) }\end{array}$ & Daily feeding rate & Times a day \\
\hline $\mathbf{2 0 - 2 5}$ & $8-10 \%$ & $3-4$ \\
\hline $\mathbf{5 0 - 1 0 0}$ & $6-8 \%$ & $3-4$ \\
\hline $\mathbf{1 0 0 - 2 0 0}$ & $5-6 \%$ & 3 \\
\hline$>\mathbf{2 0 0}$ & $1.5-4 \%$ & 3 \\
\hline
\end{tabular}

(Source: Francis and Esa, 2016)

(Note: The feeding chart provided is based on the works of the authors mentioned above. The daily feeding rates and doses can be altered in compliance with the changing temperature and other environmental conditions)

Sex reversal by the immersion technique is achieved by immersing the eggs in different concentrations of 17a-MT exposed for different period of time. The mechanism of action of the immersion technique is that the hormone is absorbed by passive diffusion across the egg membrane. During the embryonic development, gonadal differentiation can be affected by the administration of steroid sex hormone (Francis and Esa, 2016; Syarifuddin et al., 2019) in the holding water. About $91 \%$ of male population was attained when $O$. niloticus eggs were immersed in $17 \alpha-\mathrm{MT}$ (Cagauan et al., 2004) However, this technique presents conflicting results possibly 
due to the rapid early development that limits the window of opportunity (Phelps and Popma, 2000) and these results are lower than those obtained with the oral administration (Francis and Esa, 2016)

\section{Monosex tilapia culture}

Feed preparation plays a pivotal role in the culture of monosex tilapia (Wangpen, 1996; Rahman et al., 2019). The feed is prepared by an alcohol evaporation method (Wangpen, 1996; Francis and Esa, 2016). Ordinary fish ration (filler) is mixed at (40 to $60 \%$ ) with a high protein fish meal substitute of roughly $60 \%$ protein, which is used as base. The hormone, $17 \alpha-\mathrm{MT}$ is dissolved in a solvent (methanol or ethanol) at a rate of $60-70 \mathrm{mg}$ of hormone/L solvent. The prepared mixture is added to the feed at a rate of $60-70 \mathrm{mg} / \mathrm{kg}$ feed, hand-mixed thoroughly and allowed to air dry. This is done 3 to 4 days prior usage. This mixture should not be stored for more than 4 days (Chakraborty and Baneerjee, 2009; Chakraborty et al., 2011). Brood ponds should have a firm bottom and good drainage systems (Macintosh and Little, 1995; Chakraborty et al., 2011). Brooders can be fed at $1-3 \%$ body weight/day using supplementary feeds (26-35\% crude protein). Brood ponds and its stocks should be maintained separately and care must be taken to prevent inbreeding. Re-stocking should be done every 2-3 months. Nursery ponds encounter high mortality during culture days solely due to extreme stocking densities (Guerrero III, 1986; Tsadik and Bart, 2007; Chakraborty et al., 2011).

Nursery stocks should be handled with proper care to reduce stress and mortality. Nursery ponds demand good cleaning practices using fish toxicants (rotenone) and bleach. In the grow-out phase when the growth rate stagnates, it is advised that the stock has reached its marketable size (El-Nahal et al.,
2019). Monosex tilapia takes about six months to produce a good market size [500 grams] (Fortes, 2005; Chakraborty et al., 2011). Like any other culture, monosex tilapia doesn't pose serious headaches to farmers. Monosex tilapia is raised through two steps in two ponds viz., nursing and stocking pond. This type of farming system can maximize production. Just like normal tilapia culture, the management of nursing pond and grow out ponds for monosex are quite the same. Feeding with highly protein enriched (about $35 \%$ ) feed at the rate of $10-15 \%$ of the body weight showed good results (Bhujel, 2000). Feeding can be done 3-4 times a day. When the monosex attains a weight of approximately 20-30 grams (40-60 days of culture) they can be transferred to the stocking pond. Care must be taken to reduce stress. Application of good quality organic manure can lead to exponential growth of natural feed and hence the use of supplementary feed gets limited. After the monosex attains a weight of 100 grams each, feeding can be reduced to $5 \%$ of body weight. The feeding chart of monosex tilapia is shown in Table 3.

The use of dugout pond is one of the primitive systems used in the production of monosex tilapia seeds (Trong et al., 2013). Culture in hapas is more popular when compared to dugout ponds whereas culture in concrete tanks has received extensive popularity from various monosex fishers recently (Bentsen et al., 1998; Bhujel, 2000; Ghosal et al., 2015; Sarker et al., 2017). Despite all this information available on the production protocols of larval rearing, hatchability and the absorption of yolk sac still remains unique to different geographical locations (Bhujel, 2000). Production is a biological process that must remain unchanged. The major problem of insufficient quality tilapia seeds must be addressed. 


\section{Tank culture}

Fry (21-28 days post hatching) are stocked for culture from brood ponds after being sorted using a $2.5 \mathrm{~mm}$ mesh. Those passing through the mesh are used for sex-reversal and range from approximately 7-11 $\mathrm{mm}$ in length. They are stocked in tanks initially where they are chemically treated for diseases and parasites, which they may have assimilated (Shevgoor $e t$ al., 1994; Faruk et al., 2019; Razzak et al., 2019). They are then moved to the culture tanks at high stocking densities (5000-6000 per cubic metre). The biologically filtered water is made to recirculate inside the culture tanks at a temperature of $23-26^{\circ} \mathrm{C}$. Feeding is done at a rate of $20 \%$ body weight and 4 times daily (Chakraborty et al., 2011). The sex-reversal cycle takes approximately 28-30 days and the feeding rate is gradually reduced to $10 \%$ body weight at the near end of the cycle (Thongprajukaew and Rodjaroen, 2020). Weekly sampling of the fry is a necessity and this facilitates the check on feeding rates. Ectoparasitic infestations should be carefully monitored with the use of proper prophylactics. During the treatment period, the growth rate is slow due to high stocking densities and maintenance of low treatment temperatures (Faruk et al., 2019). On completion of the treatment, fry are stocked in separate nursery ponds for rapid growth prior to their stocking in production ponds.

\section{Cage culture}

Cage monosex culture has developed recent popularity in India (Chakraborty et al., 2007; Ghosal et al., 2015; Sarker et al., 2017; Balkhande, 2019). Fry (21-28 days post hatching) are passed through a $3.1 \mathrm{~mm}$ mesh to remove fry larger than $14 \mathrm{~mm}$ (Moniruzzaman et al., 2015). The smaller fry are stocked in cages of mesh size $1.5 \mathrm{~mm}$ at densities of approximately 2000-3000 per square metre. The fry are fed on the hormone augmented feed 4 times daily starting at 20\% body weight at the initial phase of the treatment cycle and reducing to $10 \%$ at completion. The fry in the cages show more significant growth than those in 'clear' water (Kembenya, 2020). The fry are then removed from the cages at the cycle end and stocked in nursery ponds where they are fed on a normal diet. The possible disadvantage of this technique is the loss of thousands of "partially sex-reversed fry" during removal of nets or cages (Kembenya, 2020).

\section{Harvesting}

Harvesting of monosex tilapia requires the use of a seine and implements two methods: partial harvesting and drain-down (total) harvesting (Shevgoor et al., 1994; Meyer et al., 1997; Sarker et al., 2017). Partial harvesting involves pulling a seine to remove the larger marketable fish and leaving the smaller ones to attain marketable sizes whereas a total harvest is achieved by draining the whole pond and removing all the stocked fish. This is usually done with several seine hauls. Typically, the period between a partial harvest and a total harvest is approximately two weeks. Fish should be harvested in the early hours of the day or at evening to prevent undue stress. Care should also be taken to keep them fresh and transfer them as quickly as possible with good handling practices.

In conclusion the monosex tilapia farming has taken an important role in the fish farming business throughout the world (Sunny et al., 2019). Monosex tilapia has great demand and value in the local as well as the international market. A profitable culture of monosex tilapia depends on two important factors, viz., good farm management practices and proper stocking (Lorenzen, 2000; Lovshin et al., 2000; Atul, 2019). On the other hand, monetary investment is quite low when 
compared to other cyprinid and non-cyprinid fishes (Atul, 2019). As a result, monosex tilapia farming rate is growing day by day and have attracted small local fishers. Their ability to grow at extensive stocking densities, good feed intake, extensive growth rates, survivability and high disease resistance make them an excellent species for aquaculture (Sunny et al., 2019). Their ability to grow along Indian major carps (IMCs) in different culture systems also makes them flexible (Ghosal et al., 2015). Their opportunistic feeding behaviour also interests fishers. However, the main hindrance to the commercial market is the hormonal augmentation which may pose threats to the consumers as a residue after culture. Extensive studies are needed and maybe one day, monosex tilapia may become a candidate species in aquaculture.

\section{Funding}

The authors declare there is no source of funding.

\section{Ethical statement}

The authors declare there are no ethical conflicts in regard with this article.

\section{References}

Abo-Al-Ela, H. G., 2018. Hormones and fish monosex farming: A spotlight on immunity. Fish Shellfish Immunol. 72, 23-30.

Abucay, J.S., Mair, G.C., 1997. Hormonal sex reversal of tilapia: implications of hormone treatment application in closed water systems. Aquaculture Res. 28, $841 \quad-\quad 845$. https://doi.org/10.1046/j.13652109.1997.00878.x.

Atul, S. K., 2019. Emerging issues and sustainability of booming tilapia production in India. Int. J. Zool. Invest. 5, 43-51.

Balkhande, J. V., 2019. Cage culture of Oreochromis mossambicus (Tilapia) in back water of river Godavari, Nanded, Maharashtra India. MOJ Ecol. Environ. 4, 100-105.

Baroiller, J. F., Chourrout, D., Fostier, A., Jalabert, B., 1995 Temperature and sex chromosomes govern sex ratios of the mouth-brooding cichlid fish Oreochromis niloticus. J. Exp. Zool. 273, 216-223. https://doi.org/10.1002/jez.1402730306. Baroiller, J. F., D'Cotta, H., Bezault, E., Wessels, S., Hoerstgen-Schwark, G., 2009. Tilapia sex determination: where temperature and genetics meet. Comp. Biochem. Physiol. A Mol. Integr. Physiol. 153, $30-38$ https://doi.org/10.1016/j.cbpa.2008.11.0 18.

Beardmore, J. A., Mair, G. C., Lewis, R. I., 2001. Monosex male production in finfish as exemplified by tilapia: applications, problems, and prospects. In: Reproductive Biotechnology in Finfish Aquaculture. Elsevier, pp. 283301.

Belton, B., Little, D.C., 2007. The Development of Aquaculture in Central Thailand: Domestic Demand versus Export-Led Production. J. Agrar. Chang. $\quad 8, \quad 123-143$. https://doi.org/10.1111/j.14710366.2007.00165.x.

Bentsen, H. B., Eknath, A. E., Palada-de Vera, M. S., Danting, J. C., Bolivar, H. L., Reyes, R. A., Dionisio, E. E., Longalong, F. M., Circa, A. V., Tayamen, M. M., Gjerde, B., 1998. Genetic improvement of farmed tilapias: growth performance in a complete diallel experiment with eight strains of Oreochromis niloticus. Aquaculture. 160, 145-173. 
Bhujel, R. C., 2000. A review of strategies for the management of Nile tilapia (Oreochromis niloticus) broodfish in seed production systems, especially hapa-based systems. Aquaculture. 181, 37-59. https://doi.org/10.1016/s00448486(99)00217-3.

Cagauan, A. G., Baleta, F. N., Abucay, J. S., 2004. Sex reversal of Nile tilapia, Oreochromis niloticus L. by egg immersion technique: The effect of hormone concentration and immersion time. Manila, (Phillipines), 127-136.

Celik, I., Guner, Y., Celik, P., 2011. Effect of orally-administered $17 \alpha$ Methyltestosterone at different doses on the sex reversal of the Nile tilapia (Oreochromis niloticus, Linneaus 1758). J. Anim. Vet. Adv. 10, 853-857. http://dx.doi.org/10.3923/javaa.2011.85 3.857 .

Chakraborty, S. B., Mazumdar, D., Chatterji, U., and Banerjee, S., 2011. Growth of mixed-sex and monosex Nile tilapia in different culture systems. Turk. J. Fish. Aquat. Sci. 11, 131-138. http://dx.doi.org/10.4194/trjfas.2011.01 17.

Chakraborty, S.B., Banerjee, S., 2009. Culture of monosex Nile tilapia under different traditional and non-traditional methods in India. World J. Fish Mar. Sci. 1, 212217.

Chakraborty, S.B., Sarbajna, A., Mazumdar, D., Banerjee, S., 2007. Effects of differential dose and duration of 17methyltestosterone treatment on sex reversal of Nile tilapia, Oreochromis niloticus at different age groups under Indian perspective. Asian J. Microbiol. Biotechnol. Environ. Sci. 9, 705-710.

Chávez-García, R., Contreras-Ramos, A., Ortega-Camarillo, C., Figueroa-Lucero, G., Prado-Flores, G., MendozaMartínez, G., Vergara-Onofre, M., 2020. Morphometric comparison of the growth curve in Nile tilapia (Oreochromis niloticus) sexually reverted to masculinized and feminized. Lat. Am. J. Aquat. Res. 48, $1-6$.

Costa-Pierce, B. A., Riedel, R., 2000. Fisheries ecology of the tilapias in subtropical lakes of the United States. In: Costa-Pierce, B.A. and Rakocy, J., Eds., Tilapia Aquaculture in the Americas, Vol. 2. The World Aquaculture Society, Baton Rouge, p. $1-20$.

El-Kassas, S., Abdo, S. E., Abosheashaa, W., Mohamed, R., Moustafa, E. M., Helal, M. A., El-Naggar, K. 2020., Growth performance, serum lipid profile, intestinal morphometry, and growth and lipid indicator gene expression analysis of mono-sex Nile tilapia fed Moringa oleifera leaf powder. Aquaculture Rep. 18, 100422. https://doi.org/10.1016/j.aqrep.2020.100 422.

El-Nahal, S. S., Amer, M. A., Osman, M. F., Ali, T. A., 2019. An assessment study of growth performance and gonads development of monosex nile tilapia in different age stages during the production period. Arab Univ. J. Agri. Sci. 27, 395-404.

El-Sayed, A. F. M., 2019. Tilapia culture. Academic Press.

FAO, 2012. The State of Food Insecurity in the World, 2012. Economic growth is necessary but not sufficient to accelerate reduction of hunger and malnutrition. The Food and Agricultural Organisation, Rome.

FAO, 2017. Social and Economic Performance of tilapia farming in Africa, 2017. Food and Agriculture Organization of the United Nations. Rome.

Faruk, M. A. R., Akter, S., Ferdous, Z., Rana, K. S., 2019. Individual and combined 
effects of two selected chemicals on bacterial load during transportation of tilapia (Oreochromis niloticus) fry. Asian J. Med. Biol. Res. 5, 14-19.

Felix, E., Avwemoya, F.E., Abah, A., 2019. Some methods of monosex tilapia production: A review. Int. J. Fish. Aquat. Stud. 4, 42-49.

Fortes, R. D., 2005. Review of techniques and practices in controlling tilapia populations and identification of methods that may have practical applications in Nauru including a national tilapia plan. Aquaculture Technical Paper/Secretariat of the Pacific Community, pp. 55.

Francis, N. O., Esa, Y. B., 2016. A review of production protocols used in producing economically viable monosex tilapia. J. Fish. Aquat. Sci. 11,1. https://dx.doi.org/10.3923/jfas.2016.1.1 1.

Fuentes-Silva, C., Soto-Zarazúa, G.M., Torres-Pacheco, I., Guevara-González, R.G., García-Trejo, J.F., Flores-Rangel, A., Caballero-Pérez, J., CruzHernández, A., 2015. Influence of extended photoperiod on all male Nile tilapia (Oreochromis niloticus) production, differential gene expression and growth rate. Int. J. Agric. Biol. 17.

Gale, W. L., Fitzpatrick, M. S., Schreck, C. B., 1996. Masculinization of Nile tilapia (Oreochromis niloticus) through immersion in $17 \alpha$-methyltestosterone or $17 \alpha$-methyldihydrotestosterone. PD/A CRSP Thirteenth Annual Technical Report Oregon Cooperative Fishery Research Unit, Department of Fisheries and Wildlife, Oregon State University.

Ghosal, I., Mukherjee, D., Chakraborty, S.B., 2015. Culture of Indian Major Carps with monosex tilapia for sustainable utilization of aquatic resources. J. Environ. Sociobiol. 12.

Green, B.W., Verrica, K.L., Fitzpatrick, M.S.,
1997. Fry and fingerling production. In: Egna, H.S., Boyd, C.E. (Eds.), Dynamics of Pond Aquaculture. CRC Press, Boca Raton, pp. 215 - 243.

Guerrero III, R.D., 1986. Production of Nile tilapia fry and fingerlings in earthen ponds at Pila, Laguna, Philippines. In: Maclean, J.L., Dizon, L.B., Hosillos, L.V. (Eds.), The First Asian Fisheries Forum. Asian Fisheries Society, Manila, Philippines, pp. 49 - 52.

Karim, M., Zafar, A., Ali, M., 2017. Growth and production of monosex tilapia (Oreochromis niloticus) under different feeding frequencies in pond conditions. J. Aquac. Mar. Biol. 6, 00167. https://doi.org/10.15406/jamb.2017.06.0 0167.

Kembenya, E. M., 2020. Growth Performance of Mixed sex and Monosex male Tilapia (Oreochromis niloticus) Reared in Cages, Lake Victoria, Kenya. In 13th International Conference.

Kuebutornye, F. K., Abarike, E. D., 2020. The contribution of medicinal plants to tilapia aquaculture: a review. Aquac. Int. 1-19.

Little, D. C., Bhujel, R. C., Pham, T. A., 2003. Advanced nursing of mixed-sex and mono-sex tilapia (Oreochromis niloticus) fry, and its impact on subsequent growth in fertilized ponds. Aquaculture. 221, 265-276. http://dx.doi.org/10.1016/S00448486(03)00008-5.

Little, D.C., Hulata, G., 2000. Strategies for tilapia seed production. In: Beveridge, M.C.M., Mc Andrew, B.J. (Eds.), Tilapias: Biology and Exploitation. Fish and Fisheries Series, vol. 25. Kluwer, Dordrecht, pp. 267 - 326.

Little, D.C., Turner, W.A., Bhujel, R.C., 1997. Commercialization of a hatchery process to produce MT-treated Nile tilapia in Thailand. In: Alston, D.E., Green, B.W., Clifford, H.C. (Eds.), IV 
Symposium on aquaculture in Central America: focussing on shrimp and tilapia, $22-24$ April 1997, Tegucigalpa, Honduras. Asociacion Nacional de Acuicultores de Honduras and the Latin American Chapter of the World Aquaculture Society, vol. 237, pp. $108-118$.

Lorenzen, K., 2000. Population dynamics and management. In: Beveridge, M.C.M., McAndrew, B.J. (Eds.), Tilapias: Biology and Exploitation. Fish and Fisheries Series, vol. 25. Kluwer, Dordrecht, pp. $163-226$.

Lovshin, L.L., Schwartz, N.B., Hatch, U., 2000. Impacts of integrated fish culture on resource limited farms in Guatemala and Panama. International Center for Aquaculture and Aquatic Environments, Alabama Agricultural Experiment Station, Auburn University, Auburn, Alabama, Research and Development Series No. 46, October 2000. 29 pp.

Macintosh, D.J., Little, D.C., 1995. Nile tilapia (Oreochromis niloticus). In: Bromage, N.R., Roberts, R.J. (Eds.), Broodstock Management and Egg and Larval Quality. Institute of Aquaculture/Blackwell Science, UK, pp. $277-320$.

Mair, G. C., Abucay, J. S., Beardmore, J. A., Skibinski, D. O., 1995. Growth performance trials of genetically male tilapia (GMT) derived from YY-males in Oreochromis niloticus L.: On station comparisons with mixed sex and sex reversed male populations. Aquaculture. 137, 313-323. https://doi.org/10.1016/00448486(95)01110-2.

Mehrim, A. I., Khalil, F. F., Farrag, F. H., Refaey, M. M., 2019. 17 $\alpha$ methyltestosterone and some medicine plants as reproductive controller agents of Oreochromis niloticus. J. Biol. Sci. 19 , 407-417. https://dx.doi.org/10.3923/jbs.2019.407. 417.

Mengistu, S. B., Mulder, H. A., Benzie, J. A., Komen, H., 2020. A systematic literature review of the major factors causing yield gap by affecting growth, feed conversion ratio and survival in Nile tilapia

(Oreochromis niloticus). Rev. Aquaculture. 12. 524541. https://doi.org/10.1111/raq.12331.

Meyer, D.E., Torres, D., Aceituno, C., 1997. Comparscion del Cultivo de Tilapia con dos Technologias diferentes. In: Alston, D.E., Green, B.W., Clifford, H.C. (Eds.), IV Symposium on aquaculture in Central America: focusing on shrimp and tilapias. National Association of Honduran Aquaculturists and the Latin American Chapter of the World Aquaculture Society 22 - 24th April 1997, Tegucigalpa, Honduras. National Association of Honduran Aquaculturists and the Latin American Chapter of the World Aquaculture Society, pp. 228 229. Chap. 56.

Mlalila, N., Mahika, C., Kalombo, L., Swai, H., Hilonga, A., 2015. Human food safety and environmental hazards associated with the use of methyltestosterone and other steroids in production of all-male tilapia. Environ. Sci. Pollut. R. 22, 4922-4931.

Moniruzzaman, M., Uddin, K.B., Basak, S., Mahmud, Y., Zaher, M., Bai, S.C., 2015. Effects of stocking density on growth, body composition, yield and economic returns of monosex tilapia (Oreochromis niloticus L.) under cage culture system in Kaptai Lake of Bangladesh. J. Aquac. Res. Dev. 6, 1.

Mukherjee, D., Ghosal, I., Hancz, C., Chakraborty, S. B., 2018. Dietary administration of plant extracts for production of monosex tilapia: Searching a suitable alternative to synthetic steroids in tilapia 
culture. Turk. J. Fish Aquat. Sci. 18, 267-275.

Noakes, D.L.G., Balon, E.K., 1982. Life histories of tilapias: an evolutionary perspective. In: Pullin, R.S.V., LoweMcConnell, R.H. (Eds.), The Biology and Culture of Tilapias. ICLARM Conference Proceedings, vol. 7. International Centre for Living Aquatic Resources Management, Manila, Philippines, pp. $61-82$.

Penman, D. J., McAndrew, B. J., 2000. Genetics for the management and improvement of cultured tilapias. In Tilapias: Biology and exploitation. Springer, Dordrecht. p. 227-266.

Pham, T.A., Little, D.C., Mair, G.C., 1998. Genetic effects on comparative growth performance of all-male Oreochromis niloticus. Aquaculture. 159, 293 - 302.

Phelps, R. P., Popma, T. J., 2000. Sex reversal of tilapia. In: Tilapia aquaculture in the Americas, Vol. 2, The World Aquaculture Society, Baton Rouge, p. 34-59.

Popma, T.J., Lovshin, L.L., 1996. Worldwide prospects for commercial production of tilapia. Research Development Series, vol. 41. Department of Fisheries and Allied Aquaculture Auburn University, AL, USA. 23 pp.

Prabu, E., Rajagopalsamy, C. B. T., Ahilan, B., Jeevagan, I. J. M. A., Renuhadevi, M., 2019. Tilapia-an excellent candidate species for world aquaculture: a review. Annu. Res. Rev. Biol. 1-14. https://doi.org/10.9734/arrb/2019/v31i3 30052.

Rahman, Z., Mamun, A., Ahmad, I., Rashid, I., 2019. Influence of Probiotics on the Growth Performance of Sex Reversed Nile Tilapia (Oreochromis niloticus, Linnaeus, 1758) Fry. J. Aquac. Res. Dev. 10, 1-7.

Ramnarine, I. W., Singh, D., 2005. Interaction between hormone concentration and water temperature on masculinization of tilapia fry. Trop. Agric. 82. 74-77

Razzak, M., Yousuf, M., Jahan, S., Nahar, N., 2019. Investigation of common diseases on cage reared Nile tilapia (Oreochromis niloticus) in Bakergonj, Barishal, Bangladesh. Bangladesh J. Fish. Res. 31, 261-270.

Sarker, S., Basak, S.C., Hasan, J., Hossain, M.S., Rahman, M.M., Ahsanul Islam, M., 2017. Production in small scale aquaculture farm: A success story from Bangladesh. J. Agric. Res. Dev. 8, 515.

Sayed, A. E. D., Farrag, M., Abdelaty, B., Toutou, M., Muhammad, O., 2018. Histological alterations in some organs of monosex tilapia (Oreochromis niloticus, Linnaeus, 1758) produced using methyltestosterone. Egypt J. Aquat. Biol. Fish. 22, 141-151. https://dx.doi.org/10.21608/ejabf.2018.1 3272.

Shevgoor, L., Knud-Hansen, C.F., Edwards, P., 1994. An assessment of the role of buffalo manure for pond culture of tilapia. III. Limiting factors. Aquaculture 126, 107 - 118. https://doi.org/10.1016/00448486(94)90252-6.

Snake, M., Maluwa, A., Zidana, H., Chigwechokha, P., Simwaka, M., 2020. Production of a predominantly male tilapia progeny using two Malawian tilapias, Oreochromis shiranus and Oreochromis karongae. Aquacult. Rep. 16, 100274 https://doi.org/10.1016/j.aqrep.2020.100 274.

Sosa, I.D.L.A.B., Adillo, M.D.L.J., Ibanez, A.L., Figueroa, J.L.I.A., 2005. Variability of tilapia (Oreochromis spp.) introduced in Mexico: Morphometric, meristic and genetic characters. J. Appl. Ichthyol. 20, 7-10. https://doi.org/10.1111/j.14390426.2004.00445.x. 
Soto-Zarazúa, G. M., Peniche-Vera, R., RicoGarcia, E., Toledano-Ayala, M., Ocampo-Velázquez, R., Herrera-Ruiz, G., 2011. An automated recirculation aquaculture system based on fuzzy logic control for aquaculture production of tilapia (Oreochromis niloticus). Aquac. Int. 19, 797-808 http://dx.doi.org/10.1007/s10499-0109397-5.

Subasinghe, R., Soto, D., Jia, J. 2009. Global aquaculture and its role in sustainable development. Rev. Aquac. 1, 2-9. https://doi.org/10.1111/J.17535131.2008.01002.X.

Sunny, A. R., Islam, M. M., Rahman, M., Miah, M. Y., Mostafiz, M., Islam, N., Hossain, M. Z., Chowdhury, M. A., Islam, M. A., Keus, H. J., 2019. Cost effective aquaponics for food security and income of farming households in coastal Bangladesh. Eqypt. J. Aquat. Res. 45, 89-97. https://dx.doi.org/10.1016/j.ejar.2019.0 1.003 .

Suseno, D. N., Luqman, E. M., Lamid, M., Mukti, A. T., Suprayudi, M. A., 2020. Residual impact of $17 \alpha$ methyltestosterone and histopathological changes in sex-reversed Nile tilapia (Oreochromis niloticus). Asian Pac. J. Reprod. 9, 3743. https://doi.org/10.4103/23050500.275527.

Syarifuddin, Y. N., Sri, A., Yenny, R., Rahem, F. A., 2019. Masculinization of tilapia (Oreochromis niloticus) by immersion method using methanol extract of pasak bumi roots (Eurycoma longifolia). Russ. J. Agric. Socio-Econ. Sci. 93.

Thongprajukaew, K., Rodjaroen, S., 2020. The optimal period for changing the feeding regime of mono-sex male Nile tilapia (Oreochromis niloticus). Aquaculture Rep. 17, 100392.

https://doi.org/10.1016/j.aqrep.2020.100 392.

Trọng, T. Q., van Arendonk, J. A., Komen, H., 2013. Genetic parameters for reproductive traits in female Nile tilapia (Oreochromis niloticus): I. Spawning success and time to spawn. Aquaculture. 416, 57-64.

Tsadik, G.G., Bart, A.N., 2007. Effects of feeding, stocking density and waterflow rate on fecundity, spawning frequency and egg quality of Nile tilapia, Oreochromis niloticus (L.). Aquaculture. 272, 380-388.

Wang, H. P., Piferrer, F., Chen, S., Shen, Z. G., 2019. Sex control in aquaculture. John Wiley \& Sons, Incorporated.

Wang, M., Lu, M., 2016. Tilapia polyculture: a global review. Aquac. Res., 47, 23632374. https://doi.org/10.1111/are.12708.

Wangpen, P., 1996. Nursing strategies for MT monosex tilapia fry (Oreochromis niloticus Linnaeus). MSc. Dissertation. Asian Institute of Technology, Thailand. $121 \mathrm{pp}$.

\section{How to cite this article:}

Avishek Bardhan, S. K. Sau, Sanjib Khatua, Madhabendu Bera and Paul, B. N. 2021. A Review on the Production and Culture Techniques of Monosex Tilapia. Int.J.Curr.Microbiol.App.Sci. 10(01): 565-577. doi: https://doi.org/10.20546/ijcmas.2021.1001.069 